\title{
STOSUNEK ŚW. IRENEUSZA Z LYONU DO INNOWIERCÓW
}

W II w. zyciu $i$ egzystencj1 Koscioła Chrystusowego zagroziky kontrowersje wynikające z przeciwności zachodzących między chrześcijaństwem, judaizmem a hellenizmem. Najbardziej niebezplecznym rezultatem tych kontrowersji było powstanie oraz wzmozona działalność róznorodnych ruchów heretyckich, mniej lub więcej powiązanych z gnostycyzmem ${ }^{1}$. Nic więc dziwnego, ze bardzo szybko doszło do decydującej konfrontacj1 Kościoła z tego rodzaju ruchami. Konfrontacja dotyczyła zarówno źródła, jak i treści prawdy chrześcijańskłej. ortodoksyjnego zaś stanowiska pierwotnego Kościoła w tych sprawach nie reprezentowali teolodzy, pisarze lub inni nauczyciele chrześcijańscy, lecz tylko i wyłącznie biskupi jako nauczający przewodnicy zgromadzeń eucharystycznych. Głównym świadkiem tego procesu by biskup Lyonu św. Ireneusz, sam bezpośrednio zaangażowany w ówczesne konflikty ${ }^{2}$. Z pozostawionej spuścizny literackiej moźna dzisiaj nie tylko łatwo odtworzyć jego postawę wobec Innowierców, ale również stwierdzić, że była ona równocześnte świadectwem oficjalnych pozycji zajmowanych przez Kościół pierwotny wobec ludzi nie wyznających czystej chrześcijańskiej wiary.

Pisząc dzieła o charakterze teologicznym, Ireneusz nigdy nie zapomniał, ze był przede wszystkim biskupem Kościoła. Dlatego tez w swoich studiach poruszal zwłaszcza zagadnienia pasto-

1 Jak twierdzi S.Pieszczoch /Patrologia. Wprowadzenie w studium ojców Kościoła, Poznaú-Warszawa-Lublin 1964,70-71/, popularność tych szkół była tak wielka w II w., iż w tym czasie ich literatura przeważała 1lościowo nad ortodoksyjnz literatura chrześcijańską; por, tez: B.Altaner, Patrologie, Freiburg im Breisgau 1938, 72. Pełniejsze omówienie problemu gnostycyzmu por.: M.Baur, Anfunge der Christenheit, Von Jesus von Nazareth zur Pruhchristlichen Kirche, Berlin 19764, 199-209; P.Pierrard, Historia Kościoła katolickiego, tłum. T.Szaṕrański, Warszawa 1981, 34-36; J.Daniélou - H.I.Marrou, Historia Kościoła, t.1: Od początków do roku 600, tłum. M.Tarnowska, Warszawa 1984, 59-67, 89-100, 115-117.

2 Por.: Danlélou - Marrou, IIistoria Kościoła, dz.cyt., 99-100; J.Zizioulas, Episkope et Église primitive. Brê inventaire de la documentation, "Irénikon" 56/1983/484-502, 490. 
ralne świadom powierzonego sobie posłannictwa, które dzięki sukcesj1 sięgało samego Jezusa Chrystusa ${ }^{3}$. Ukierunkowana pastoralnie ogólna postawa badawcza ukształtowała zapewne specyfike ireneuszowego stosunku do ruchów 1 szkół heretyckich, której istotna cechą było praktyczne uznanie pozytymnego wykładu doktryny Kościoła apostolsklego za najdonioślejszy element sprzeciwu wobec niebezpleczeństwa heretyckiego ${ }^{4}$. Wbrew potocznej opinil, Swiety Biskup Lyonu z II w. nie uwazał za element wiodący krytycznej analizy ruchów 1 szkół heretyckich, o czym najlepiej świadczy fakt, ze w obu jego dzlełach, znanych obecnie $\nabla$ całośc1, bezpośrednie opinie o herezjach towarzyszą tylko ortodoksyjnemu wykładow1 nauczania kościelnego lub zawarte sa w jego zakończeniu.

Ireneusz chociaz nie dał systematycznego wykładu własnego poglądu na sprawę innowierców, to jednak przedstawił jasno swoje,a zarazem kościelne stanowisko na temat ruchów 1 szkół heretyckich. Omawlając je należ uwzględnić kolejno ireneuszowa interpretację genealogii 1 istoty ruchów heretyckich jako rzeczywistości antyewangelizacyjnej, praktyczność jego podejścia do Innowierców oraz miłość jako ostateczne źródło ewangelizacji innowierców.

\section{ANTYEWANGELIZACYJNA GENEALOGIA I ISTOTA HEREZJI}

Wysuwając argumenty przeciwko "wszystkim heretykom" swojego czasu, Ireneusz musiał najpierw poszukać historycznego źródła zjawiska herezji. Według niego wszystkie herezje narodziły się nie tyle $z$ aktymośc1 ludzkiego intelektu, p̣le $z$ aktymości istoty ludzkiej wziętej w całej jej rzeczymistości. Inicjatorem wszelkich herezj1 by $\mathbf{z}$ Symon Mag ${ }^{5}$. Po to, aby otrzymać od ludzi najwyższe uwielbienie, ogłosił on siebie samego subtelną siła, tj. ojcem, który

3 Adversus haereses II 17, 1, SCh 294, 156. Por. Ph. Vielhauer, Geschichte der urchristlichen Literatur. Einleitung in das Neue Testament, die Apokryphen und die Apostolischen Vater, Berlin New York 1975, 205,217,237; L.Bouyer, Kościół Bozy. Mistyczne Ciało Chrystusa i świł̨tynia Ducha Bożego, tłum. W.Krzyzaniak, Warszawa $1977,332$.

4 Por. E.Lanne, Le Symbole des Apôtres, expression de la fol apostolique et lé Symbole de Nicée, "Irénikon" 56/1983/467-487, 472. 5 Adversus haereses I 23,2, SCh 264,314; por. II praef. 2, SCh 294, 
Jest ponad wszystkim. Ta dumna proklamacja była tylko ostateczna konsekwencja Innego błędu Szymona, opłsanego przez świątego Lukasza w Diejach Apostolskich /8, 9-24/. Do danych skrypturystycznych Ireneusz dodał informacje, że ów człowiek, dostrzegajłcy w ewangelizacyjnym działaniu Chrystusa jedynie sztukę magiczną, nadającą się do kupienia za pieniądze, "nie uwlerzył Bogu 1 zapałał pożądaniem wystapienia przeciwko apostołom, aby się okazało, ze 1 on jest sławny 1 aby przez jeszcze głębsze badanie magii wywołać u wielu ludzi podziw" 6 . Ostatecznym owocem przewrotrej działalności człowieka z wadliwym stosunkiem do Boga był pierwszy ruch heretycki w łonie młodego Kościoła.

Wszystkie naczelne błędy odnalezione przez Ireneusza w ruchach heretyckich jego czasów, posiadały swoje odpowiedniki w działalności Szymona Maga. Jeszcze bardzièj Jednak znacząca dla niniejszego studium jest inna informacja zawarta w wyzej zacytowanych słowach naszego staroźytnego teologa. Zgodnie z nią, poczł̨tek wszystkich herezji wiazał się ścí́le z ewangelizacja. Ireneusz był tak zajęty ową myśla podczas opisywania szymonowej dzlałalności, ze uzyl tutaj słowa "ewangelizować". Co więcej, dostarczył on dodatkowej informacji, według której właśnie akt niewiary wobec doświadczenia działającego Boga dał początek nieporozumieniu spychającemu Szymona Maga wherezję ${ }^{7}$. Błąd ów przejęli wszyscy inni innowiercy, którzy dalej rozwinęli nauczanie Szymona. Oni wszyscy takze naśladowali Szymona Maga używając magil w swolch zwodniczych praktykach.

Rozwój historyczny był oczywíscie procesem, do którego przyczyniły sił całe generacje heretyków. Kolejni następcy Szymona Maga: Menander z Samari1, Satornil z Antiochi1, Bazylides 1 Karpokrates tak rozwijali heretyckie nauczanie o Bogu, iz od błędów na temat stworzenia poprzez błędna chrystologie 1 soteriologie doszli do błędnego nauczania o istocie ewangelizacji Kościoła. Inni heretycy,

6 Tamże I 23,1, SCh 264,314.

7 Tamże, por. N.Brox, Offenbarung, Gnosis und gnostischer Mythos bei Irentus von Lyon. Zur Charakteristik der Systeme, Salzburg Mutnchen 1966, 183 .

8 Por. Adversus haereses I 23,5 = I 25,4, SCh 264, 320-340; M.BaIwierz, The Holy Spirit and the Church as a Subject of Evangelization according to St. Irenaeus, Harszawa 1985, 82. Te 1reneuszo- 
Jak np. Cerynt uczący o zstąpieniu Chrystusa-Siły na Jezusa z Nazaretu podczas jego chrztu w Jordanie ${ }^{9}$, dodawali konieczne detale do nauczania głównych przywódców ruchów heretyckich.

Wozystkie doktrynalne pomyłki dodawane powoll przez pokolenta Innowierców, odnalazł Ireneusz w teoriach gnostyckich Ptolemeusza, Marcjona, Walentyna $i$ Marka Maga ${ }^{10}$. W perfidny sposób wszystkie te warianty gnozy mniej lub wiecej nadużywały swej argumentacj 1 Pisma świętego na korzyść własnych fałszywych teorii. To waśnie wydaje się być racją, dla której Ireneusz skłonny był uważać heretycki ruch kierowany przez Marka Maga za rzeczywistość nadzwyczaj niebezpieozną dla życia Kościoła ${ }^{11}$. Należy pamiętać o tym, ze Ireneusz był przede wszystkim biskupem konkretnej wspólnoty kościelnej. Marek Mag uwiódł wcześniej kilkanaście niewiast będących członkiniami Kościoła lokalnego, na którego czele stał Ireneusz ${ }^{12}$. Biskup Lyonu musiał zareagować na ten fakt. Jednym z pierwszych rezultatów takiej reakcji była dobra znajomość nieprawości dokonywanych przez innowiercóv, z których wcale nie najgorsza była błędna doktryna. Dopuszczali się oni bowiem także bałwochwalstwa, prowadzili niemoralne życie, naduzywali elementów chrześcijarískich 1 td. Całość togo zjawiska Ireneusz wyjaśnłł teologicznie w oparciu o zasadę generalną stwierdzająca, iz brak wiary prowadzi ludzi do magi1. Z tej racj1 wszystkich czytelntków swolch dzieł pouczał następująco:

"Przede wszystkim argumentuje się to przeciw tym, którzy są od Symona 1 Karpokratesa albo tez 1 Innym, którzy mówią, że działają siłą: tego co czynią, nie powodują ani Siła Boża, ani Prawda, an1 nie dla dobra ludzi, lecz w zatraceniu 1 błędzie, przez 1 luzje magiczną 1 powszechny fałsz wį̨cej szkodzą, niz dają

we poglądy streszcza także P.Płerrard /dz.cyt., 35/, jednakże bez powoływania się na konkretna wypowiedz Biskupa Lyonu.

9 Por. Adversus haereses I 26,1, SCh 264, 344-346. Myśl tę powtarza za nikolaitami: III 11,1, SCh 211, 138-140.

10 Tych cztereoh Innowierców Ireneusz uznał za czołowych przedstawicieli "fałszywej gnozy" - por.: H.J.Jaschke, Der Helilge Geist im Bekenntnis der Kirche. Eine Studie zur Pneumatologie des Irentus von Lyon $1 \mathrm{~m}$ Ausgang vom altchristlichen Glaubenbekentnis, Mtlnster $1976,175 \mathrm{n}$.

11 Por. Adversus haereses II, praef. 1, SCh 294,22. Według Ph. Bacqa De l'ancienne à la nouveile Alliance selon S.Irénée. L'Unite du Livre IV de l'"Adversus Haereses", Par1s 1978, 24-29/ 1rene- 
pozytku tym wszystkim, którzy im wierzą w tym, do czego uwodzzin 13 .

Ze słóm tych wynika, ze Ireneusz ocenia działalność heretycka w podwójny sposób. Uwaźał, ze wszystko to, co czynill innowiercy, byto oparte na sile magil 1 fałszerstwa 1 miało jedynie za cel skłanianie prostych ludzi do złego. Dlatego współczesna Ireneuszowi działalność Innowierców upodobniała ich do Szymona Maga. Z tej właśnie racjl odrózntali się onl całkowicie od Jezusa Chrystusa 1 jego uczniów ${ }^{14}$. Jako duszpasterz, Biskup Lyonu, zaczął uwazać ów zwodniczy, antyewangelizacyjny charakter ruchów heretyckich za najbardziej istotne zagrożenie życia kościelnego. Dlatego tez bezlitosnie zdemaskował go z wszystkimi szczegółami w swoich dziełach. Ukazana przez Ireneusza prawda o antyewangelizacyjnej istocie ruchó heretyckich $w$ szczególności dotyczyła heretyckiego uwodzenia do niemoralnego zycia, ataku Innowierców na działalność Kościoła oraz nadużywania ewangelizującego Kościoła przez propagatorów herezji.

$$
\text { 1. Her e t y ck } 1 \text { e u w o d z e n } 1 \text { e d o n } 1 \text { e - }
$$

m o r a 1 n e g o z y c 1 a. H.J. Jaschke zebral 1 przedstawil ireneuszowe informacje o moralności gnostyków. Dotycza one zarówno ich nauczania, jak 1 praktyk. W obu tych dziedzinach Biskup Lyonu wspomniał dwie główne pomyłki heretyków: libertynizm i rygorystyczny ascetyzm ${ }^{15}$. Jaschke nie zauwazy jednak tego, ze Ireneusz opisał obydwa błędy gnostyków jako rzeczywistości związane z ich aktywnym działaniem, służącym propagowaniu herezj1 wóród ludzi. Tymczasem wydaje się, ze nasz starożytny Teolog wyjaśniz wszystkie fakty dotyczące heretyckiej niemoralności jedynie wowiazaniu z ewangelizacją.

uszowa argumentacja przeciwko gnostyckiej egzegezie fałszujacej Pismo św. była głóñ kwestia polemice z Innowiercami. 
Na zapisanych przez Ireneusza kartach niewiele można znaleźć informacji o rygorystycznym ascetyzmie innowierców. Biskup Lyonu wspomniał o celibacie niektórych gnostyków tylko jako o rzeczywistości służącej "zwodzeniu wielu ludzi". I tylko raz jeszcze napisał on o tej praktyce niektórych heretyków, podkreślając, iz ów celibat jest znakiem czarnej niewdzięczności, a konsekwentnie 1 bluźnierstwem przeciwko Bogu, Stwórcy wszechrzeczy. Tacjan wprowadziz tego rodzaju rzeczywistość do ruchów heretyckich ${ }^{16}$. Z takiego potraktowania rygorystycznego ascetyzmu heretyckiego przez naszego teologa staje się jasne, ze dla Ireneusza istotne zło herezj1 jako całości tkwi zarówno w jef charakterze zwodniczym, jak 1 bluźnierczym.

W nieco odmienny sposób opisał Biskup Lyonu zwiazek pomiędzy gnostyckim libertynizmem 1 heretyckim odpowiednikiem ewangelizacj 1 chrześcijańskiej. iozwiązłość przywódców ruchów gnostyckich była w istocie rzeczy osia ich całej aktywności ukierunkowanej na zdobycie nowych wyznawców, a zwłaszcza kobiet. Jest to konkluzja sugerowana czytelnikowi "Adversus Haereses" przez długi opis aktywnośc1 Marka Maga ${ }^{17}$. Ireneusz nie pominął równiez tego faktu, że uczniowie Marka całkowicie naśladowali swojego mistrza. Pisał więc otwarcie:
"A 1 uczniowie jego dobrze zaprawient w tym samym, zepsuli wiele kobiet przez uwiedzenie. A sami siz nazywaja doskonałymi. Prawie nikt nie może zrównać sie z ogromem 1ch wiedzy - mówiz, że nawet ani Paweł, ani 1 Plotr lub jacyś inni apostołowie. Albowiem sami najwiecej ze wszystkich posiedli wiedzy 1 ogro- mu znajomości tejże, która jest niewypowiedzianą siłą, sami jedynie siq napili. Sa zatem sami powy- zef wszelkief Siły, a dlatego 1 wolnymi do czynie- nia czegokolwiek. A przy tym żadnego w niczym nie maja strachu"18.

W słowach tych Biskup Lyonu zawarł także ważną wypowiedź na temat zasadniczych błędów popełnianych przez innowierców.

Według Ireneusza zachowanie moralne innowierców doprowadziło

16 Por. Adversus haereses I 24,2, SCh 264, 322-324; I 28, 1, SCh 264, 354-356.

17 Por. Adversus haereses I 13, 1-7, SCh 264, 188-204. Zgodnie ze swoja pozytywna opinia o inteligencji $x$ pragnieniach czytelnika, Ireneusz pozostawiz mu wycỉsgnięcie konkluzji z tej informacji
zawierającej wiele szczegółów.

18 Tamże I-13,6, SCh 264, 200-202. 
ich do głównego błędu "fałszywej gnozy". Jest nim ujęcie człowieka jako istoty całkowicie równej Bogu, który stworzył 1 uporząakował cały wszechówiat ${ }^{19}$. Nasz Teolog jasno wypowledzlal się w tym punkcie. Taki błąd istnieje zarówno w życiu, jak 1 w doktrynie heretyków. Co więcej, sam porzłdek przedstawionych zastrzeżeń wobec całościowej postawy przyjętej przez innowierców poucza czytelnika o tym, że $1 \mathrm{ch}$ błı̨d generalny nie jest jedynym ujemnym rezultatem tch praktyk moralnych. Innym jest całość $1 \mathrm{ch}$ nauk1, poniewaz w istocie rzeczy, aby usprawledliwić libertynlzm moralny, nauczali on doktryn, które oczywiście są błędne. Ireneusz szczegółowo wyliczył dwa punkty węzłowe nauczania heretyckiego:

- Innowiercy twierdzz, iż tylko on 1 uczestnicza w najwyższej sile pośród pojmowalnych rzeczy, dlatego tez tylko oni posiadajiz ostateczny autorytet dla nauczania innych lurlzi prawdy;

- nawet apostołowie uchybiajacy temu uczestnictwu nie mogą posiadać większego autorytetu niź ów prominentnych gnostyków. Pozostaje oczywistym faktem to, że Ireneusz widzlal całość sprawy opisanej przez dopiero co zacytowane słowa w świetle swoich myśli teologicznych, dotyczących ewangellzacj1 kościelnej 1 jej heretyckiego odpowiednika. On nie tylko poinformowal czytelnika o tym, iz w ramach ludzkich działalności innowiercy posiadaja antytyp ewangelızacji posiadanej przez członków Kościoła, ale równieź ocenił go bardzo surowo. Uczynił to z dwóch powodów. Po pierwsze, doktrynalnie oparł on taka ocenę na kłamliwym odrzuceniu istnienia zła przez heretyków. Po drugie, stwierdził, iź bafwochwalcze praktyki innowierców majaz swój poczłtek nie w życiu i działalności Jezusa Chrystusa oraz jego apostołów, ale w działalności pogańskiego Poncjusza Piła$\mathbf{t a}^{20}$. Racj $\mathbf{z}$ bardzo surowej oceny herezji przez Ireneusza była działalność innowierców, w której wprost atakowali prawdziwą owangelizację kościelną.

2. A t a k i n n o w i e $r$ c ó $w$ na d z 1 a 1 a 1 $n \circ s$ ś $K$ oś c $i$ o 1 a. Ewangelizacyjniz działalność Koścloła

19 Tamie, por. D. Devoti, Teıi escatologici nello gnosticismo valentiniano, "Augustinianum" 18/1978/47-61, 53; Jascike, Pneuma und Moral, art.cyt., 252,256.

20 Por. Adversus haereses I 25, 5-6, SCh 264, 340-344. 
Chrystusowego heretycy atakowali zarówno teoretycznie, jak 1 praktycznie. Atak teoretyczny związany był ściśle z antyewangelizacją genezz ruchów heretyckich.

Na początku III księgi "Adversus Haereses" Biskup Lyonu dostarczył przepięknego opisu relacji istniejących pomiędzy ewangelizacją kościelną a jej heretyckim przeciwieństwem ${ }^{21}$. Przy tej okazji Ireneusz wypowiedział swoje główne osłarżenie wobec każdego innowiercy. Sprowadza się ono do twierdzenia, ze Bożą "mądrość, gdziekolwiek by nie była, nazywają swoj zwłasną". Jest to oczywiście błędna odpowiedź człowieka na objawienie Boże, ponieważ prawie wcale nie pozostawia ona miejsca na wiare obejmujaca poddanie sie człowieka Bogu. Brak owej wiary z poddaniem sie Bogu jest poczztkiem błędów heretykóm. Taki właśnie brak wlary był powodem niemoty Zachariasza - ojca Jana Chrzciciela, kamienowania Pawła oraz Barnaby w Lystrze $e^{22}$. On również powoduje próżność doktrynalnych wymysłów gnostyckich. Przeciwko temu szczególnemu owocowi działalności nieprzyjaciół Bożych jest skierowana prawdziwa ewangelizacja prowadzona przez samego Boga, działajłcego w Kościele. Dlatego jego członkowie próbujz ewangelizować innowierców, posługując siz przy tym argumentacja z Pisma świętego i Tradycji. Niestety, nowy akt niewiary heretyckiej powoduje teraz ich atak doktrynalny na samą ewangelizację kościelną. Pismu świętenu zarzucają on1, iż jest nieautentyczne, nieautorytatywne lub w błędnej wersj1. Ustrzeżonej tylko wościele Tradycji apostolskiej nie uznają ani za jedynz, ani za najważniejszł, ani za prawdziwa, ponieważ sądzł, że sami tylko posiadajz prawdziwie tajemne przekazy otrzymane od Boga z pominięciem pośrednictwa nie tylko apostolskiego, ale 1 Chrystusowego. Takie ataki nie moga jednak powstrzymać aktywności Kościoła, który nieustannie pobudza swoich członków do wzmożenia ich własnych wysiłków, zmierzajłcych do realizacji kościelnego obowi zzku ewangelizowania wszystkich ludzi.

Ruchy heretyckie atakowały prawdziwa ewangelizacje nie tylko na poziomie doktrynalnym. Jako realia niebezpieczne dla zbawienia prostych chrześcijan, mniej lub więcej atakowały one tę część

21 Por. tamże III 2, 1-3, SCh 211, 24-28; I 27,4, SCh 264, 352-354.

22 Por. Fragmentum L, PG 7, 1264 A; Adversus haereses III 12,9, SCh 211,222; Balwierz, The Holy Spirit, dz.cyt., 39, 
ewangelizacji kościelnej, która kierowała się do jego członków. Istotą tego ataku była obfitość, sugestywność 1 natarczywość propagandy heretyckiej. Przy niepełnej znajomości pochodzenia, moralności i faktycznej znajomości wartośc1 ruchów heretyckich owa propaganda wystawiała prostych chrześcijan na łup dla innowierców, podobnie jak bezbronne owce są wystawione na łup dla wilków. Takie niebezpieczeństwo najgroźniejsze było dla neofitów - wiennch najbardziej zależnych od ewangelizacji wewnątrzkościelnej ${ }^{23}$. Ruchy heretyckie były również niebezpieczne dla ewangelizacji pogan. Zwłaszcza gnostyckie pojęcie Boga oparte na naturalnym pojęciu człowieka mogło być bardzo łatwo zaakceptowane przez ludzi, którzy Go wcale nie znali ${ }^{24}$. Istotnie ruchy takie były dziełem szatańskim, skierowanym przeciwko misji Kościoła, o czym Ireneusz wypowiedział się jasno:

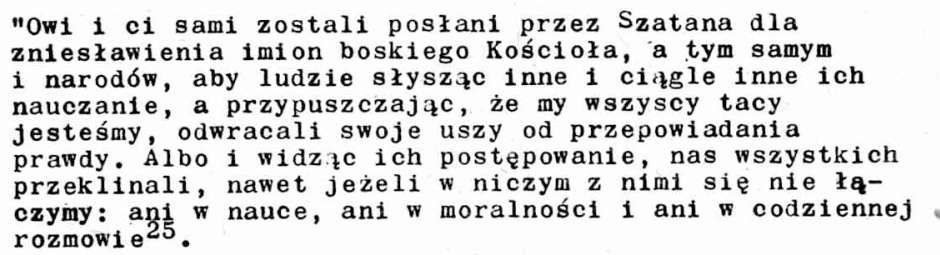

Zgodnie zatem ze wskazanymi przez Ireneusza faktami chrześcijanie, nie mając nic wspólnego z innowiercami, próbuja poprawiać ich praktyczne, teoretyczne 1 propagandowe błędy. Ludziom prostym trudno jednak to spostrzec i sytuacja taka nie sprzyja ich ewangelizacj1.

Wspomniana wyżej próba zdyskredytowania ewangelizującego Kościoła wcale nie była uważana przez Ireneusza za najbardziej perfidną formę ataku na ewangelizację. Wydaje się, że za takaz formę Biskup Lyonu uważał próby nadużywania Kościoła i jego ewangelizacji dla propagowanta idei heretyckich. Dlatego temu szczegółowemu zagadnieniu poświęcił on znaczną cześć swojej uwagi.

23 Por. Adversus haereses I, praef. 2, SCh 264, 20-24; V, praef. SCh 153, 12 .

24 Por. tanże II 2,4, SCh $294,38$.

25 Tamze I $25,3, \mathrm{SCh} 264,336-338$. 
3. N a d u z y

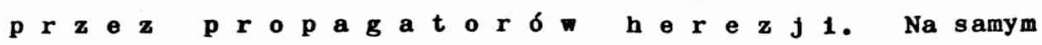
początku "Adversus Haereses" Ireneusz podkreśla, ze heretycy nie pomagaja realizacji Ekonomii Bozej, która jest rzeczywistościa obejmujaca prawdziwa wiarę. Na tym polu innowiercy działali jak wilki ukryte pod skórami owiec. Próbowali oni wyrazić własną doktryne tych samych słowach, jakich uzywall prowadzący ewangelizacje chrześcijanie. Lecz nie nadawali oni tym słowom chrześcijańskiego znaczenia. Pó́niej, znowu nazywając heretyków nwilkami w owczych skórach", nasz starozytny Teolog wskazal na niewiare tych ludai jako na ostateczną racje dla swojej opinil o nich ${ }^{26}$. Generalna mýs Ireneusza jest jasna. Brak wiary u Innowieró́w determinował zarówno relację heretyków z Ekonomią Bożą, jak 1 chrześcijańską - tym opinię. Zgodnie z tą opinia Kościoła, heretycy szkodzili Ekonomil Bozej przez naduzywanie elementów ewangelizacji kościelnej. Nic zatem dzimnego, 1ż ewangelizujący Kościół ocenił ich negatywnie.

Biskup lyoński zauwazył również to, iź osąd Kościoła nie był przyjmowany przez heretyków. Uczyli bowiem oni, ze wierzą dokładnie w ten sam sposób, jak Kościół. Ireneusz jednak stwierdził, ze przez takie oświadczenie innowiercy próbowali jedynie zyská wiecej wyznawców, których uczyli tylko próźnósci 1 niemoralnego zycia 27 . Naturalnie, tego typu ośwladczenia, jak 1 wszelkie próby zblizania się do Kościoła były jedynie usiłowaniem naduzycia samego Kościoła przy propagowaniu idei heretyckich.

Innowiercy nie tylko próbowali przedstawić swoja zwodniczą działalność jako rzeczywistość kościelną, ale usiłowali także użyć poszczególnych elementów ewangelizacji kościelnej w swoim własnym szatańskim dziele. Z wielka perfidia naduźywali chrztu, eucharystil, kapłaństwa, Ducha Proroczego 1 biblijnego pojecia łaski. Naprawdę zaś tych rzeczywistości udzielił Bóg tylko ewangelizującemu KościoIow1.

26 Por. tamże I praef. 1, SCh 264, 18-20; IV 6,6, SCh 100, 448-450; IV 15,2, SCh 100, 554-558. Według Ireneusza' przez taką dobrowolna niewiare innowiercy staja się dziećmi Szatana w sensie adopcyjnym; A. Orbe, San Ireneo adopcionista? En torno a Adv. Haer. III 19,1, "Gregortanum" 65/1984/5-52, 17-22.

27 Por. Adversus haéreses III 15,2, $\operatorname{SCh} 211,278-282$. 
Ireneusz dostarczył nam długiego opisu heretyckich doktryn 1 praktyk dotyczacych ceremonil bardzo podobnych do chrztu chrześc1jańskiego. Osobisty komentarz Biskupa Lyonu zwraca uwage czytelntka na 1ch wielość. Or brak jedności sugeruje obecność aktywnośc1 szatanisiej takze $w$ ceremoniach heretyckich ${ }^{28}$. Takie bogactwo ceremonil podobnych do chrztu chrześcijańskiego jest jednak jawnym naduzyciem elementu ewangelizacji sakramentalnej, poniewaz służy jedynie przyciąganiu ludzi do ruchów heretyckich przez budzente Ich zdziwienia 1 ciekawości.

Aby na przykład umieść wybraną kobietę, Marek Mag imitował Inna ceremonię chrześcijańską. Wprowadził mianowicle sztukę magiczną do rytu mającego swój wzór w chrześcijańskiej celebracji eucharyst11. Wypowiadając mnóstwo słów, symulował po prostu chrześc1jańska konsekrację wina. Ostatecznie tak wszystko urządzał, iź coś czerwonego pokazywało się wałym kielichu. Jego wasne słowa zgrabnie podpowiadały wszystkim obecnym ludziom, ze ten czerwony płyn jest krwią pewnej "łaski z niebios". Następnie zapraszał kobiety do wypow Ladania dziękczynienia /"eucharistein"/ nad tym małym kielichem. Zdaje się, ze $w$ ten właśnie sposób Marek zapraszał koblety do "koncelebrowania" z nim samym. Gdy kobieta wybrana przez Marka do uwiedzenta wypowiedziała swoje słowa, rozpoczynała s1ę nowa część tej maskarady. "Konsekrowaną" przez kobietę zawartością małego kielicha Marek napełniał inny, znacznie większy. Znowu jego własne słowa podpowiadały wszystkim obecnym ludziom a zwraszcza owej biednej oflerze jego sztuki magicznej - ze to ona sama pełna jest jakiejó łask1-gnozy, która spowodowała ten cud. Takimi 1 podobnymi sztuczkami Marek Mag duchowo zabił, $t j$. zwiódł do herezj1, wielu ludzi ${ }^{29}$. Gnostyk ten, zgodnie z relacja Ireneusza, potrafił naduzyc jednocześnte trzech elementów ewange-

28 Por. tamże I 21, 1-5, SCh 264, 298-308; A.Houss1au, Le baptême selon Irénée de Lyon, EThL 60/1984/ 45-59, zwł • 51-52.

29 Por. Adversus haereses I 13,2, SCh 264, 190-192. Ireneuszowe oskarzenie innowierców o nadużywanie ewangelizującego Kościola, staje sie wyraźniejsze po odczytaniu tego tekstu na tle Jego nauczania o Eucharystii /por. R.Daly, The Origine of the

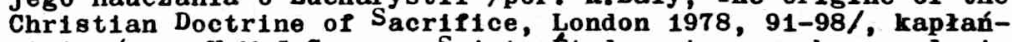
stwie/por. Y.M.J.Congar, Sainte Etudes et approches ooclesiologiques, Paris 1963, 243/ 1 kasce/por. A.Houssiau, La Christo- . logie de'Saint Irenee, Louvain 1955, 109-114/. 
I1zującego Kościoła: eucharysti1 1 kapłaństwa oraz biblijnej ide1 raski.

Dla uwodzenia ludzi Marek Mag nadużywał także chrześcijańskiego daru Ducha Prorockiego. Markowa zdolność sugerowania czegoś innym ludziom odgrywała znaczna role w tym inspirowanym przez Szatana procesie. Dlatego używał on tej sztuki przede wszystkim wobec szlachetnych $i$ bogatych niewiast, które były bardziej podatne na uwiedzenie przez pochlebstwo. Taka kobietę zaczepiał bezczelnie długa mowa pochlebczą, która zawierała równiez słowa o swego rodzaju unil istniejącej między nim a zaczepioną szlachcianką. ostatecznie, jako osoba będąca w posiadaniu doskonałej gnozy, Marek rozkazywał jej wypowiedzieć jakieś proroctwo 1 nastawał na to tak długo, aż ofiara zaczynała wierzyć w jego słowa i próbowała prorokowac. o ile Szatan pomagał tutaj Markow1, to kobieta w końcu zaczynała wierzyć, 1z sama jest prorokinicz 1 pożądać swojego całkowitego zjednoczenia z osobą swojego "dobroczyńcy", także przez stosunek cielesny ${ }^{30}$. Przy tym opisie Ireneusz nie powtórzył juź konkluzj1 z relacji o "cudach" Marka. Po prostu, inteligentny czytelnik "Adversus Haereses" wcale tego nie potrzebował.

Tedług A.Harnacka, w II wieku chrześcijaństwo stało się religią bardziej instytucjonalną, gubiąc równocześnte oryginalne wartośc1 "Ducha 1 siły". Taka tezę, zdaniem owego badacza, maja potwierdzać niektóre fakty wspomniane przez Ireneusza. Harnack jednak nie uwzględnił 1reneuszowego świadectwa o dopiero co opisanych Paktach ${ }^{31}$. Pozwalały one lepiej ujrzé́ całą sytuację chrześc1jaństwa II wieku, whórym naczelnym zagadnieniem była prawdziwa ewangelizacja, a więc zmaganie się ortodoksji z ruchami heretyckimi. Zmagania te same już były ewangelizacją. Wydaje się - przynajmniej odnośnie do świadectwa ireneuszowego - iz w tej skomplikowanej sytuacji musiały pojawiać się pewne zmiany w reczywistości zwa-

30 Por. Adversus haereses I 13,3, SCh 264, 192-196. Równiez to oskarzenie nabiera odpowiedniego wyrazu dopiero po przeczytaniu tekstu w kontekście ireneuszowego nauczania o Duchu Prorockim/por. Jaschke, Der Heilige Geist, dz.cyt. 233-249\%.

31 A.Harnack, The Mission and Expansion of Christianity in the First Three Centuries, New York 1962, 204-205. 
nej "Duchem 1 siłą". Nie była to żadna utrata takiego "Ducha 1 siły" przez chrześcijaństwo. Ireneuszowe myśl1 o stosunku do innowierców oraz o ostatecznym źródle tej postawy zdają się niedwuznacznie śwladczyć na korzyóć tej obserwacjl.

\section{PRAKTYCZNE PODEJŚCIE IRENEUSZA DO INNOWIERC OW}

Krótkle studium nad motywami skłaniającymi Ireneusza do podjęcia działalności pisarskiej prowadzi do ciekawego wniosku ${ }^{32}$, ze nie wypływała ona ani z jego osobistego zamiłowania do tego rodzaju pracy, ani z zainteresowania rozwojem teologil, ani tez z pasji do polemiki, lecz z pełnej świadomości ciążący na nim specjalnych obowiązków chrześcijańskich 1 biskupich. W tym punkcie mozna postawié nowe pytanie: Czy Ireneusz sądz1ł, ze sam ewangel1zuje-Innowierców przez działalność badacza 1 pisarza? Twierdząca odpowiedź na to pytanie sugeruja niektóre motywy podane przez niego, aby ukazać pożyteczność własnej publikacji.

Na samym początku "Adversus Haereses" Biskup Lyonu deklaruje, iz pisze te stronice, poniewaz musi podjąć aktywne działante przec1wko ludzıom, którzy "nauczaja fałszywych słow ... 1 przez owe nieudolnie wytwarzane podobieństwo zmieniają ich sens dla ludzi, którzy nie są znawcami oraz prowadzą $1 \mathrm{ch}$ w ntewolę, fałszując słowa Pańskie /...//33. Bez wdawania się w dyskusję o głównym zarzucie postawionym przez Ireneusza gnostycyzmowi, trzeba zauważyé, ze jest on plerwszym, z wszystkich, jakie można znaleźé w jego dziełach. Na kartach "Adversus Haereses" powtarza się on jak refren 34 Dlatego tez wydaje się, iz ta obiekcja jest jednym z głównych motywóm Inspirujących Ireneusza do podjęc1a trudu zmagań $z$ herezjami. Jedną z jego wielkich nadziei było pozbawienie skuteczności heretyck 1 ej propagandy.

Reakcja na propagandę heretycką nie była jednak główną racją

32 Por. Balwierz, The Holy Spirit, dz.cyt., 49-50.

33 Adversus haereses I praef. 1, SCh 264,18 .

34 Por. tamże I $8,1, \operatorname{SCh} 264,112-116$; I 25, 6, SCh 264,342; I 26, 4 , SCh 264, 352-354; II 13,9 , SCh 294,126 ; II 31,2 , SCh 294, 328; II $32,3, \operatorname{SCh} 294,338$; III 17,4, SCh 211, 338-340; III 19, 1, SCh 211,372; III 23,8, SCh 211, 466-468; IV 27,4, SCh 100, 
dla Ireneuszowej troski o Innowierców. Biskup Lyonu wskazał na n1a w następujacych słowach:

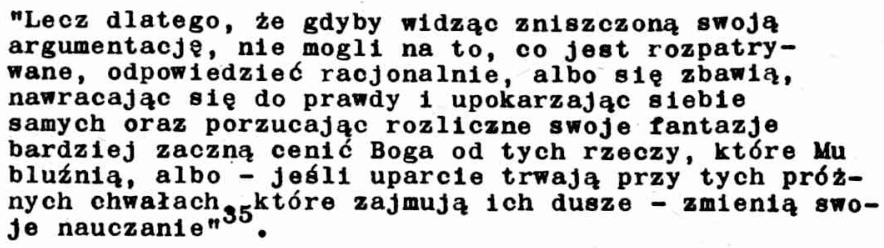

Z samego porządku podanych tutaj racj1 jest oczywiste, ze w odn1esieniu do heretyków Ireneusz był zainteresowany czyms więcej niz tylko zahamowaniem zewnętrznej skutecznośc1 1 ch grzechów, czy zblizeniem ich do prawdy. Jego największą troską było osobiste zbawienle Innowierców.

Zgodnie z treścia ostatnio cytowanej wypowiedz1, Ireneusz kazda herezje uwazal za rodzaj grzesznego bluźnierstwa. Próbując pomóc tego rodzaju grzesznikom, radziz im najpierw porzucić heretyckie bluźnierstwo. Następnie powinnt ont pojednać sie z Bogiem przez wasne uniżente się przed Nim. Według Biskupa lyońskiego takie nawrócente jest jedyną droga prawdziwego zbawienta dla innowierców. Jednym z celów skłanłajz̨cych Ireneusza do podjęcia działalności badawczo-pisarskiej było przypominanie tef prawdy - koniecznośc1 nawrócenia wszystkim zainteresowanym. Nasz starozytny Pisarz nigdy o tym nie zapomnial ${ }^{36}$, co niewątpliwie f́wiadczy o dużej stabilności 1 powadze jego troski duszpasterskiej obejmujacej Innowierców.

Dostrzezenie głębokie troski Ireneusza o zbawienie innowierców prowadzi do innej clekawej obserwacji. Dotyczy ona całego tła ujmowania przez Biskupa Lyonu procesu nawrócenta. Zgodnie z tym ujęclem pochodzący z Kościoła innowiercy nie są w ten sam sposób

T46-750; V 3,3, $\operatorname{SCh} 153,48-54$.

35 Tamże II 11,2, SCh 294,94 .

36 Por. tamze I 31,3, SCh 264,388; II 28,4, SCh 294, 278-280; III 6,4 , SCh 211, 74-76; III 25,7, SCh 211, 488-490;' IV praef. 1-2, SCh 100, 382-384; IV 41,4, SCh 100, 992-994; V praef. SCh 153, 
poza Kościołem, jak poganie. Chociaz pozostają oni na zewnątrz Kościoła jako chrześcijanie rozbijający jego jedność przez oddalenie od prawdy, to jednak maja $z$ nim wieksze wiezzy niz ludzie wcale nie znający Boga ${ }^{37}$. Dlatego pomimo uzycia raczej mocnych epitetów dla denominacji herezji, Ireneusz sądził, ze heretycy uczciwie próbuja wierzyć woga, a 1 ch błąd polega jedynie na czynieniu tego w zły sposób. Taka pomyłka wiedzie ich ostatecznie do bluźnierstwa 1 do głoszenia Boga, który w rzeczywistości nie istnieje ${ }^{38}$. Ta myśl Biskupa Lyonu świadczy, 1 ż w swojej ocenie zjawiska herezji dostrzegał 1 uwzględniał dobrą wolę innowierców.

Należy zauważć, że dla Ireneusza kazdy rodzaj wiary, nawet błędnej, w sposób konieczny łączy się z praktycznym jej ujawnieniem wobec innych ludzi. Ta sama zasada rządziła równiez osobistą aktywnością Biskupa Lyonu. W procesịe podawania ksiag czytelnikow 1, Autor nasz po wyłożeniu 1 krytycznym odrzuceniu doktryny heretyckiej, rozpoczął wykład prawdziwej myśl1 skrypturystycznej, przedstawiając ten sposób wiarę Kościoła. Tak1 jednak wykład wykraczał poza granice czytelnikowej prośby o dostarczenie mu broni przeciw heretyckiej działalności. Z tej racji przedstawiona przez Ireneusza nauka Kościoła jest w istocie rzeczy darem Bozej miłośc1 - tej miłości, która zawsze daje więoej niż to jest oczekiwane ${ }^{39}$. Synteza takiego ireneuszowego nauczania zdaje sie być stwierdzenie, iz to jego osobista wiara inspirowana ogniem Bozej miłości skłoniła go do wyłożenia innowiercom prawdy powierzonej Kośc1ołowi.

Ogarniająca całe stworzenie miłość Boga realizuje się miłości jego wyznawców. Z tej tez racji pierwszym obowiazkiem chrześcijan jest miłować, nawet nieprzyjaciół. Ireneusz wiedział, ze od tej zasady nie ma zadnych wyjatków ${ }^{40}$. Dlatego zawsze by gotowy zaofe-

37 Por. Brox, Offenbarung, dz.cyt., 22-35. Ta mý́l Ireneusza jest prawie identyczna ze współczesnymi wypowiedziami Kościoła Nauczającego o przyporządkowanym Kośclołowi kręgu ekumenicznym /por. Pawel VI, Ecclesiam suam 109-111 1 Sobór Watykański II, KK 13,15/.

38 Por. Adversus haereses II, 28, 4, SCh 294, 278-280.

39 Por. tamze III praef., SCh 211,18.

40 Por. Jaschke, Pneuma und Moral, art.cyt., 257, 266-273. 
rować heretykom "Rękę", która pomogłaby im osiągnąć własne zbawienie. A Paktycznie sam próbowal usuwać niektóre przeszkody z drog1 Innowlerców do owej "Ręki". Jak jednak zauważa sam Ireneusz, jest to wszystko bolesnym, ale koniecznym procesem, bardzo podobnym do medycznej troski o chora osobę. P1sał o tym wprost:

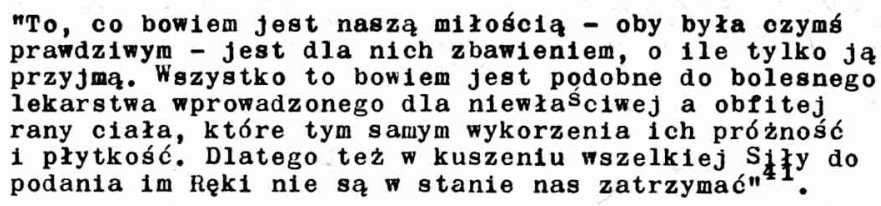

Przy takim oświadczeniu staje się jasne, że jeżell osobista wiara skłoniła Ireneusza do wyłozenia innowiercom prawdziwej doktryny, to jego miłość przynaglała go do troszczenta się o ich zbawienie. Odnotować tu jeszcze należy jedną szczegółową myśl naszego starożytnego teologa - że nie ma żadnej różnicy pomiędzy prawdziwą miłością do innych ludzi a ich zbawieniem. A zatem w swojej totalnej egzystencji prawdziwa miłość przekracza granice aktywności indyw1dualnego człowieka 1 obejmuje aktywność także innych członków ludzkości /"o lle tylko ja przyjmą"/. Spostrzeżenie to sugeruje, $1 z$ Błskup Lyonu myślał o prawdziwej miłości dokładnie w ten sam sposób, w jaki myślaz on o wierze: musi być praktycznie ujawniana wobec innych osób. Co więcej, na pozlomie ludzkiej aktywności, ujętej na tle relacji pomiędzy człowiekiem a Bogiem, Ireneusz zdaje się rozumieć wiare 1 miłość jako jedna rzeczywistość, która przynagla chrześc1jan do podjęcia działań związanych z propagowaniem zbawienia.

Takie odczytanie doplero co zacytowanych ireneuszowych słów zdaje się być uzasadnioną mozliwością tylko wtedy, gdy są one przede wszystkim wypowiedzią teologiczną. Na korzyść tego twierdzenia świadczą następujące obserwacje:

- te słowa Ireneusza należa do większego fragmentu jego pism, który w istocie rzeczy jest osobistą modlitwą $1 \mathrm{ch}$ autora ${ }^{42}$;

41 Adversus haereses III 25,7, SCh $211,490$.

42 Tamze, "My zatem błagamy ..." /SCh $211,488 /$, "... o to sie 
- dla naszego pisarza słowo "Ręka" posiadało ściśle teologiczne znaczenie $i$ było uzywane dla zdenominowania podmiotu Bożej aktywności poza Nim samym; juz wcześniej J.Lawson wykazał, ze temat "Dwóch Rąk Boga" ma biblijne pochodzenie, lecz został on rozwinięty przez Ireneusza jako opozycja do postulowanych przez systemy gnostyckie eonów pośrednich ${ }^{43} ;$ zdaje się, iz na tym tle w wypowiedzi Biskupa Lyonu o oczywistych innowiercach istnieje tylko jedna 1 jedyna mozliwość interpretacji słowa "Ręka", mianowicie jako słowo posiadającego ściśle teologiczne znaczenie ${ }^{44}$; podobnie to samo znaczenie należy suponować w całym kontekście tego słowa;

- Ireneuszowa teologia ewangelizacji jest związana z rzeczywistościa określaną przez słowo "Siła" to odnotowane; obecność tego samego słowa w innej wypowiedzi naszego pisarza o ewangelizacji wysuwa równleź na pierwszy plan teologieznaz myśl autora.

Pełnia zaś ireneuszowej teologii zawartej w powyżej przedstawionych słowach może być prawdziwie odczytana tylko przy uwzględnieniu jego nauczania o wierze.

Badacze dobrze już przestudiowali ireneuszowe pojęcie wiary. Ci, którzy podchodzili do niej jako do rzeczywistości kościelnej, podkreślają jego rozumjenie wiary jako rzeczywistości otrzymywanej 1 przekazywanej. W taki sposób istnieje ona $i$ wościele, 1 w indywidualnych jego członkach ${ }^{46}$. Podejście w granicach fenomenu objawienia zwraca uwage innych poszukiwaczy na ireneuszowa myśl o wierze w istocie rzeczy będącej darem Boga. Dar ten nie ogranicza wol-

43 Por. J.Lawson, The Biblical Theology of St Irenaeus, London 1948, 119-139.

44 Mimo to niektórzy współcześni badacze nie dostrzegali zacytowanego tutaj Pragmentu pism ireneuszowych /por. J,Mambrino, "Les deux mains de Dieu" dans I'oeuvre de Saint Irénée, NRTh 79/1959/ 355-370, zwł. 355; Jaschke, Der. Heilige Geist, dz.cyt., 193 przyp. 11; Bacq, De l'ancienne à la nouvelle Alliance, dz.cyt., 37 przyp. 5,76 przyp. 4,77 przyp. 1. A tymczasem sam Ireneusz napisał: "Jeżeli zatem jestés dziełem Bożym, oczekuj ręki twego Twórcy czyniz̨cej wszystko należycie, naleźycie ze względu na ciebie, który zostałeś uczyniony"/Adversus haereses IV 39, 2 , SCh 100,966/.

45 Por. Balwierz, The Holy Spirit, dz.cyt., 39,44,47.

46 Por. A.Holstein, La Tradition des apôtres chez S.Irénée, RSR 36 /1949/ 229-270/, zwł. 268-269, z dobrymi dodatkami E.Lanne w rozprawie: La ministère apostolique dans l,oeuvre de Saint Irénée, 
ności ludzkiej i dlatego daje podstawy do sądu Bożego nad ludźmi ${ }^{47}$. W końcu podejście z jeszcze bardziej antropologicznego punktu widzenia, pozwala niektórym badaczom lepiej studiować ireneuszowe ujęcie wiary jako obejmującej ludzkie dzieła miłości. H.J.Jaschke szczególnie mocno zaakcentował mýl naszego starożytnego Teologa - obopólnej nierozerwalności wiary i miłości ${ }^{48}$. Niektóre myśli Biskupa Lyonu o związku wiary z dwustronna relacją pomiędzy Bogiem a ozłowiekiem zostaky rozpoznane przez autorów tych wszystkich studiów. Najczęściej myśli te dotycza roli Ducha Swiętego w działalności człowieka wierzącego. W jednym ze swoich studiów R.Tremblay sugeruje, iż nasz starożtny Teolog rozumiał wiarę 1 miłość jako Jedną rzeczywistość będącą źródłem ludzkiej aktywności zwanej "⿱́㇒́wladectwem". Istota jedności tej rzeczywistości jest zjednoczenie w działaniu Ducha Swiętego 1 człowieka ${ }^{49}$. Te same dokładnie myśli zostały odczytane w zacytowanych powyżej słowach Ireneusza. W tym jednak wypadku jest to opis teologiczny osobistego świadectwa, jakie sam Biskup Lyonu dawał przez praktyczną realizację troski - zbawienie innowierców.

Ireneusz wypełniał ten swój szczególny obowiązek pasterski przy pomocy różnych środków. Plerwszym z nich była cała jego działalność badawczo-pisarska, w której zajmował się podwójnym wyłożeniem prawdy:

- o fenomenie "fałszywej gnozy" jako szatańskiej przeszkodzie dla zbawezej aktywności Boga i ludzi ${ }^{50}$;

- o "prawdziwej gnozie", która rzeczywiście jest źródłem zba-

"Irénikon" 25/1952/ 113-141, 127.

47 Por. J.Ford, St Irenaeus and Revelation. A theological Study, Notre Dame 1962, 19; MoUlrich, Erkenntnis aus Glauben, w: Irenaus von Lyon, Geduld des Reifens. Gottes Wiedereinhoiung der Weltgeschichte /Ausgewthlt und tbertragen von H.Urs von Balthasar/, Lelpzig 1977, 57; Bacq, De l'ancienne à la nouvelle Alliance, dz.cyt., 73 przyp. 1,211 przyp. 3,291, przyp. 2 .

48 Por.: Jaschke, Der Hellige Gelst, dz.cyt., 319-321, 340; tenże, Pneuma und Moral, art.cyt., 263-265; E.Lanne, La "xeniteia" d'Abraham dans l'oeuvre d'Irenée, "Irénikon" 47/1974/163-187,
168 n.

49 Por. R.Tremblay, Le Martyre selon Saint Irénée de Lyon, "Studia Moralia" 16/1978/167-185, 169-171, 177 .

50 Por. Adversus haereses I 21,1, SCh 264, 294 . 
wienta przez nowe narodzente sie człowieka 51 .

Działalność Ireneusza-badacza nie była odseparowana od dziazalnośc1 Ireneusza-biskupa. W "Adversus Haereses" moźna znaleźć miejsca ́́miadczące o tym na rózny sposób. Najpierw Biskup Lyonu otwarcie czasem pisze do heretyków, udzielając $1 \mathrm{~m}$ rady 1 ostrzezeń oraz wyywając $1 \mathrm{ch}$ do nawrócenia ${ }^{52}$. Inną grupe tekstow, wartych tutaj wopomnienia, stanowia osobiste modlitwy Ireneusza, w których prosi Boga o to, aby heretykom pomógł sie nawrócic ${ }^{53}$. Co więcej, zdaje sie, ze jego wyżej zacytowane słowa: "Dlatego tez w kuszeniu wszelkiej Sily do podania im Ręki nie sa w stanie nas zatrzymać", były aluzją do pewnej prośby w oficjalnej modlitwle wspólnoty, odbyæającej się pod przewodnictwem biskupa. Jest bowiem wyraźne, choclaz pośrednie, świadectwo Ireneusza o istnieniu kościelnej ceremonil przyjmowania do wspólnoty osoby opuszczającej ruch heretycki. Znajduje sie ono w jego relacji o grzechach takiej osoby wyznanych publicznie Kościołow1. Duza znajomośs szczegółów sugeruje, ze Ireneusz wielokrotnie uczestniczył osobíscle w takiej ceremonil ${ }^{54}$, oo zreszta by ło jego obowlazkiem Jako biskupa.

W tym kontekście wydaje się, iz sam Ireneusz rozumial swoja działalnóś obejmująca studia 1 pisanie jako kontynuację swej aktywności podczas liturglcznego przyjęcia heretyków do wspólnoty kościelnej. Wypełnianie obowiazku pisania nie jest aktem bluźnierstwa nawet wedy, gdy trzeba pisać bluźnlercze słowa, poniewaź angazuje sie tutaj miłość Boga ${ }^{55}$. Takie ireneuszowe widzenie sprawy jest rodzajem nadzie1. Biskup Lyonu mógł ją wzbudzać tylko dlatego, ze był ́́wiadom uczestnictwa w urzędzie, który przed nim wykonywa11 prorocy, apostołowle 1 ch uczniowie. Jako $1 \mathrm{ch}$ następa naśladował pozostawiony mu przez poprzedników przykład tego rodzaju słuzby kościelnej.

Prorocy, apostołowle 1 ich uczniowie nauczall przede wszystkim

51 Por. tamze, V 12,4, SCh 153, 154-156; IV 33,8, SCh 100, 818-820.

52 Por. tamze, dla upomnienia: IV $38,4, \operatorname{SCh} 100,958$; dla rady: IV 32,2 , SCh 100, 964-966; dla apelu: II 28,4, SCh 294,278; III 12, 11, SCh 211, 226-230; IV 9,3, SCh 100, 486-488.

53 Por, tamze III 25,7 /zacytowane powyzej, dane w przyp. 41/; III $6,4, \operatorname{SCh} 211,74-76$.

54 Por. tamze I 6,3, SCh 264, 94-96; I 13,5, SCh 264, 200.

55 Por. tamże II $30,2, \operatorname{SCh} 294,302-304$; II $17,1, \operatorname{SCh} 294,156$. 
unikania jakiegokolwiek związku z próznymi herezjami oraz niepobożnymi innowiercami ${ }^{56}$. Oni sami w zyclu trzymali się tej zasady. Nadzwyczajny tego przykład dał św. Jan Apostoł, który natychmiast opuścił łaźnie publiczne, gdy tam zobaczył Cerynta. Apostoł wyznał otwarcłe, ze herezja tego człowieka była przyczyną jego ucieczki z łaźni, późnłej zaś napisał czwartą Ewangelię przeciwko "fałszywej gnozie", gdzie w Prologu wyłożył kościelną "regułę prawdy"57. Podwójna reakcja tego Apostoła na herezje jest oczywista. Po pierwsze, uclekł od heretyka jako prosty uczeń Pański, po drugie zaś, pisał przeciwko herezjom jako uczeń, któremu Pan powierzył takie zadanie.

Ta druga działalność Jana była kontynuowana przez Jego ucznia Polikarpa. Podczas niezamierzonego spotkania otwarcie potępił on Marcjona Jako pierworodnego syna Szatana. Napisał takze list potwierdzajacy prawde, aby w ten sposób zapobiec wpływom heretyckim w Filippi. W tym szczególnym wypadku uczeń janowy postąpił za przykładem sw. Paw $\mathbf{s}^{58}$. Jest to najlepszy dowód, iz sam Polikarp rozumiał działalność antyheretycką jako obowizzek odziedziczony po wszystkich apostołach.

Nalezy więc przyjąć, że Ireneusz był całkowicie świadom wazności swojej własnej pozycji w tym względzie, poniewaź sam podkreś11 fakt bycia uczniem Polikarpa. Jako kolejny sukcesor musiał zatem wykonywać obowiązki pasterskie takze wobec innowierców ${ }^{59}$. Okazuje sie więc, ze to sukcesja apostolska była jednym z najwazniejszych motywów inspirujących ireneuszową troskę o zbawienie innowierców. Biskup Lyonu zdawal sobie sprawę $z$ tego, że sukcesyjnie nie może naśladować tylko św. Jana Apostoła 1 sw. Polikarpa. Podstaw do

56 Por. tamże I 16,3, SCh 264, 260-264。

57 Por. tanze III 3,4, SCh 211,42.

58 Por. tamze III 3,4 , SCh $211,42-44$.

59 Por. Bouyer, Koścí́ł Boży, dz.cyt., 108,392 n. Odnośnie ireneuszowej znajomości Polikarpa zob. Adversus haereses III 3,4,
SCh 211,38. 
duszpasterstwa innowi erców dostarczyły mu bowiem takze prorockie słowa przeciw herezjom zawarte w Bibli1. Juz św. Paweł pisał według niego wiście do llzymian /6,9/: "Chrystus powstawszy z martwych nigdy juz więcej nie umrze", a powiedzial to, co zostało przepowiedziane, przewidując przez Ducha takie same podziały złych nauczycieli 1 pragnąc ich pozbawić wszelkiej okazjl do złej 1nterpretacji ${ }^{60}$. Podobnie odczytywał nasz starozytny Teolog proroctwo Jeremiasza. Jego mowa przeciwko Jechoniaszowi /Jer 22, 24-31/ Jest słowem skierowanym przeciwko tym heretykom, którzy twierdzili, ze Józef jest naturalnym ojcem Jezusa Chrystusa. Wyjaśnia to blizej słowami: "Dlatego to zostało wypowiedziane o Jechoniaszu, poniewaz Duch juz wtedy wiedział o tym, co mówią źli nauczyciele" 61 .

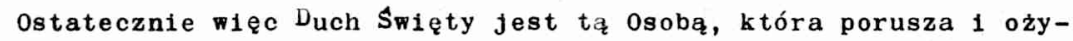
wia aktywność podmiotów ludzkich, troszczących się o zbawienie innowierców.

Ireneuszowa kontynuacja prowadzonego uprzednio przez proroków, apostołów 1 ich uczniów duszpasterstwa heretyków jest w 1 stocie rzeczy pełnaz bojaźni Bozej pokusą dla "Siły", aby oferować "Rękę" Innowiercom 62 . Jest to aktywność prawie identyczna z działalnością innych podmiotów, która Biskup Lyonu nazywa otwarcie ewangelizacja ${ }^{63}$. Zdaje się, ze myśl naszego starozytnego Teologa jest jasna, nawet wówczas jeżeli wypowiedziana została tylko pośrednio. Jako sukcesor apostolski sam ewangelizuje innowierców, a teologiczne cnoty wiary, nadziei 1 miłości tworzą podstawy tego procesu, który w 1stocie rzeczy jest dziełem Ducha Swiętego.

\section{MILOŚ́ - OSTATECZNYM ŹRODLEM EWANGELIZACJI INNOW IERC $\delta W$}

Ireneusz pisał swoje księg1 przede wszystkim dla ortodoksyjnych chrześcijan, a nie dla innowierców. Podkreślając ten fakt, wspominał równocześnie adresatom o obowiązku ewangelizowania ludzi

60 Por. Adversus haereses III 16,9, SCh 211,326.

61 Tamże, III 21,9 , SCh 211, 424-426.

62 Por。 tanże III 25,7 , zacytowane powyżej w przyp. 41.

63 Por. Balw1erz, The Holy Splrit, dz.cyt., 21-47. 
błędnie wierzących ${ }^{64}$. Fyjaśniając zaś to chrzéscijańskie zadanie, wskazywał jednoczé́nie na ostateczne źródło ewangelizacj1 innowierców prowadzonej przez członków Koścloła.

We wprowadzeniu do "Adversus Haereses" Biskup Lyonu napisal następujące słowa o swej działalnośc1: "/.../ miłość nas więc napomina $/ . . . /$, aby według łaski Bozej zostały ujawnione tch doktryny /.../". Nieco dalej dodał do tej wypowiedzi jeszcze kilka słów o aktywności osoby, która czyta jego pisma: $/$ /../ a 1 ty czyń skutecznym pozostałe posługi według łaski, jaka ci została dana przez Pana $/ \ldots / /^{65}$. W obu tych krótkich zdaniach ujawnia się jasno ireneuszowa myśl o jednym źródle inspirującym wypełnienie ogólnochrześcijańskiego obowiazzku ewangelizowanta innowierców.

Chrześcijańska słuzba 1nnym ludziom, szczególnie ta obejmuJąca ukazywante im prawdy, jest powodowana przez cnoty teologiczne, a zwłaszcza przez miłość. W istocie jednak rzeczy, dzlała przez te cnoty raska Boża, której sam Pan udziela. Na poziomie antropologlcznym ta właśnie łaska jest ostatecznym źródłem ewangel1zacj1 prowadzonej przez wierzących. Ten zaś dar Boga udzielany jest członkom Kościoła na rózne sposoby, poniewaź niektórzy z nich mogą spełniać to samo zadanie lepiej niz inni ${ }^{66}$. Hóżny więc udział indywidualnych chrześcijan w darowanej im przez Pana łasce powoduje róźnice pomiędzy osobistymi sposobami praktycznej realizacji troski o zbawienie innowierców.

Ireneusz nie rozwinął wprost tego tematu, poniewaz unikał kaźdej niepotrzebnej spekulacji nawet wtedy, gdy miała ona charakter teologiczny ${ }^{67}$. Dlatego tez myśl o freneuszowej ewangelizacji Innowierców, opartej na kasce Bozej, raz jeszcze tylko powraoa na kartach "Adversus Haereses" - w mypowiedzi o herezj1 Marcjona.

64 Por. Adversus haereses, I praef. 3, SCh 264, 24-26; Balmierz, The Holy Spirit, dz.cyt., 63-66.

65 Por. Adversus haereses I praef. 2-3, SCh 264, 20-26.

66 Ze wskazanej przypisie 64 wypowiedzl wynika, że leplej od Ireneusza zadania ewangelizacyjne wobec innowierców moze spezni 6 czytelnik jego dzieła.

67 Ta obserwacja opiera sie o 1reneuszowe potraktowanie wyjánienia udzielonego proroctwu o 1mieniu Antychrysta/por. Adversus haereses V 30,3 , SCh 153, 378-384/. 
Dojrzax on bowiem szanse krytycznego zanalizowania tej herezj1 - obrebie bardzo małego tła skrypturystycznego, stworzonego przez kilka biblijnych tekstów, przyjętych za autentyczne przez tego gnostyka. Fakt ten jest w 1stocie rzeczy darem Boga 1 Ireneusz dziękuje Mu za takq łaskę ${ }^{68}$. Motywy ireneuszowego unikania tematu łaski zdaja sie być jasne w śwletle jego wasnych zastrzezeń wobec pozycji przyjetej tutaj przez heretyków. Trzeba tylko pamiętać o tym, ze Biskup Lyonu - ta sama osoba, która obawiała s1e popełnienta bluźnierstwa przez sam fakt powtarzania gnostyckich opinil - skarcił Innowlerców za to, że "nic nie zostawiają dla Bogan'69. Uważając Boga za ostatecznego inspiratora przez swoja laske realizacjl obowiazku ewangelizowanta, Ireneusz rzeczywisc1e wolat te sprawe zostawí́ tylko Bogu. Wypada po prostu taka jego mole uszanować.

Wskazując na teologiczne cnoty wiary, nadziel 1 miłośc1 oraz na łaskę Boła jako na ostateczne źródło ewangelizacj1 innowierców, Ireneusz dawał jednocześnie świadectwo podchodzenia do całośc1 zjawiska ruchów heretyckich jedynie z pozycji wiary. Dlatego to waśnie uzasadnił przede wszystkim głęboko teologicznie swoja postawe ewangelizacyjną wobec Innowierców, rozumiejąc równiez jedynie w sposób teologiczny samo zjawisko herezj1. Była to wizja wypracowana w powiazaniu z ldeą sukcesywnie realizowanej Ekonom11.

Według Ireneusza wszystkie herezje posiadaja diabelski początek. Heretycy zaś, którzy są jedynie narzędziami uźywanym1 przez Szatana wego walce z Bogiem, zakoncza swoje istniente w taki sam sposób, jak ich przybrany ojciec, tj. w ogniu wiecznego potepienia. Nie ma zreszta lnnej mozliwości dla tych, przez których szatańska działalność skierowana przeciwko Kościołow 1 1 pogańskiej części ludzkości, usłłuje przeszkadzać zbawienłu ludzi. W tej szatańskiej dzlałalności uczestniczy osobíscie kazdy heretyk jako człowiek oddzielony od Boga, Jego miłości 1 Jego duchowej "Sily". Zamiast tych ostatnich kazdy heretyk pełen jest

68 Por. tamze I 27,4 , SCh 264,352 .

69 Tamie II 28,4, SCh 294,278 . 
fałszersitw, diabelskich poruszeń 1 fantazyjnego bałwochwalstwa, które jako całość stanowią podstawę odszczepieńczo-zwodzicielskiego natchnienia innowierców. Dlatego tez wszyscy heretycy zwiastują swoją działalnością jedynie apokaliptycznego smoka 1 osiągna ostatecznie taki san koniec jak on ${ }^{70}$. To prezentowane przez Ireneusza teologiczne wytłumaczenie zjawiska herezji dopomogło mu do zajęcla bardzo poprawnej ekumenicznie postawy wobec innowierców, a była to przede wszystkim postawa ewangelizacyjna.

Cała ekumeniczna postawa Ireneusza przepełniona jest miłościę płynąca z otrzymanej łaski Bozej. Ta właśnie miłość skłania najplerw Biskupa Lyonu do wstawiania sie za Innowiercami u Boga. Następnie budzi ona $w$ nim szlachetny motwy podjecia praktycznej ewangelizacjl innowierców w celu $1 \mathrm{ch}$ zbawienia. Mitość ta nakłania takze Ireneusza do okazania innowiercom poszanowania przez solidne studia nad lch literatura oraz prowadzenie dialogu z przywódcami ruchów innowierczych ${ }^{71}$. W końcu miłość ta pozwala mu widzieć w innowiercach jedynie biedne ofiary Szatana, którymi on się pesługuje w walce z Bogiem. Przy takim spojrzentu na innowierców, Biskup Lyonu nie miał naturalnie żadnych trudności w dostrzezeniu 1 docenteniu dobrej woll tyeh ludzi, którzy uczcíie próbuja wierzyé w Boga, ale robią to w zły sposób na skutek zwiedzenia ich przez propagandę heretycka. Dlatego też autentyczna miłość inspiruje Ireneusza przede wszystkim do takiego działania, które by ową propagandę pozbawiło wszelkiej skuteczności. Waznym elementem tego dzlałania jest wykład prawdziwej wlary, będący w swej istocie po prostu darem Bozej miłośc1. Daru tego Biskup Lyonu strzegł zwłaszcza przed płytkim irenizmem 1 indyferentyzmem re11 gijnym, unikając za przykładem apostolskim nieekumenicznych kontaktów z herezjami. Jednym słowem, inspirowana miłościa, wywodząca się z otrzymanej lask1 Bozej, praktyczna postawa Ireneusza

T0 Por. tamze I 21,1, SCh 264, 294; I 24,2, SCh 264, 322-324; I 25, 3 , SCh 264, 336-338; II 31,3, SCh 294, 330-332; v 26,2, SCh $153,332-334$.

71 Por tamze I praef. 2, SCh 264, 22; I 25,5, SCh 264, 340-342; II $17,1, \operatorname{SCh} 294,156$; II 17,9 , SCh $294,168-170$. 
wobec Innowierców zdaje się realizować przede wszystkim te wszystkie wskazówk1, Jakie współczesny Kościół Nauczający wypowiedział o dziele ewangelizacji ekumenicznej ${ }^{72}$. Tym samym okazuje się, że ekumeniczne śwladectwo 0jca Kościoła lyońskiego z II w. pozostaje nadal aktualne wościele Chrystusowym przy końcu drugiego tysiaclecia jego historil.

W rezultacie przeprowadzonych studí́w mydaje sie, iz istotą ekumenicznego świadectwa Ireneusza pozostaje spoistość jego postawy teoretycznej $i$ praktycznej wobec innowierców oraz wynikająca z tego duza konsekwencja $i$ jednolitość tak w teologii, jak 1 w postęporaniu. Pozwoliło to nie tylko Biskupow 1 Lyonu dostrzec jedność jako istotny warunek życia Kościoła, ale także nierozerwalne zwiazki jedności Ludu Bożego z jednością Nowego Przymierza oraz jedności chrześcijaństwa z jednością jednego 1 tego samego planu Bożego, zw. inaczej Ekonomiaz ${ }^{73}$.

Ks. Marian Balwierz - Lublin

\section{THE ATTITUDE OF ST. IRENAEUS OF LYON TO AISBELIVERS /Summary/}

The full approach of St. Irenaeus to the phenomenon of the heretical movements was shaped by his Christian faith. This fact allowed him first to see the nature of every heresy as an opposite reality to the Church's evangelization. In opposition to the evangelizing Church, misbelivers only seduced people to the immoral iffe. What $1 \mathrm{~s}$ more, they also attacked the activity of the Church and they even misused some elements of the Christian evangelization in order to propagate heresies. The Christian faith of Irenaeus allowed him next to see the misbelivers as being only the poor victins of the Devil, who used them as some tools in his struggle with God. Therefore, the Bishop of Lyon was trying to evangelize those misbelivers in many ways. The Christian faith, hope and love were forming the foundation of this evangelizing activity of Irenaeus. However, he knew that the last source of this activity was the God's gift of grace given to him and other Christians. The evangelizing range of Irenaeus'attitude to the misbelivers helped him to realize almost all those directions which the modern Teaching Church has spoken about the ecumenical evangelization. In this way, the ecumenical testimony of the Father of the Church from the second century is still an actual one in the Church of Christ already ending the second millenium of its history.

72 Por. Sobór Watykański II, DE 4-12.

73 Por. Pierrard, Historia Kościoła, dz.cyt., 36; F.Normann, Didaskaleion. Line Bezeichnung fur die Kirche bei liemens Alexandrinus, w: Volk Gottes. Zum Kirchenverstandnis der katholischen, evangelischen und anglikanischen Theologie, red. R.Bauner H.Dolch, Freiburg-Basel-Vien 1967, Bd,1, 84-111, 95 n.; DantélouMarrou, Historia Kościoła, dz.cyt., 100 . 